\title{
DIALOGO TIPOLOGIJA IR PROFESINIO BENDRAVIMO UŽSIENIO KALBA MOKYMAS
}

\author{
Gražina Šumskytė
}

Vilniaus universitetas, Universiteto g. 5, LT-01122 Vilnius

\begin{abstract}
Aptariamos profesinio (dalykinio) dialogo užsienio kalba gebẻjimu ugdymo galimybès remiantis dialogu tipologine klasifikacija. Šiuolaikinio užsienio kalbu mokymo tikslas - mokyti ne užsienio kalbos, o bendravimo ta kalba. Dialogini bendravima nulemia daugybè komunikaciniu pragmatiniu veiksniu (komunikacinè situacija, partneriai ir ju rangas, pokalbio tema ir kt.). Skiriami ịvairūs dialogo tipai, tad, mokant profesinio bendravimo užsienio kalba, derètu remtis tipologine dialogu klasifikacija. Straipsnyje remiamasi patirtimi, sukaupta mokant profesinio dialogo vokiečiu kalba Vilniaus universiteto bibliotekininkystès specialybès studentus. Apklausus Lietuvos ir Vokietijos didžiujų biblioteku darbuotojus ir nustačius tipines bibliotekininko ir skaitytojo bendravimo situacijas, svarbiausiais profesinio (dalykinio) dialogo tipais laikytume informacinį dialoga, probleminį dialoga ir dialogą-ginča. Straipsnyje nagrinejjamos šiu dialogu, ypač informacinio, lingvistinès ir psichologinès ypatybès (strategijos).
\end{abstract}

Reikšminiai žodžiai: dialoginio bendravimo komunikaciniai-pragmatiniai veiksniai, dialogo tipologija, (tipologinè) klasifikacija, profesinis (dalykinis) dialogas, probleminis dialogas, dialogas-ginčas, interviu schema.

\section{İvadas}

Komunikacinė užsienio kalbų mokymo metodika pradinėse pakopose dažniausiai pasitelkia dialogus, susijusius su tam tikra kasdienio bendravimo situacija. Nuo šių paprastų dialogų pamažu pereinama prie dialoginio kalbejimo, ir tada vis svarbesnè tampa pokalbio tema - kalba imama naudotis kaip priemone turiniui perteikti. Kita vertus, norint sutelkti dèmesị i pasakymo turini, būtina gebèti pakankamai laisvai vartoti kalbą. Taigi svarbiausia problema, su kuria neišvengiamai susiduria besimokantysis kalbèti užsienio kalba, - tai dilema "turinys - forma“. Pasak R. Dirveno (1977: 8), spontaniškoje šnekamojoje kalboje akivaizdžiai pasireiškia neatitikimas tarp noro išsakyti vis naujas galvon ateinančias mintis bei idejjas ir gramatikos sistemos, „nulemiančios kalbejjimą ir ìspraudžiančios ji ị tam tikras sintaksès struktūras“. Kalbejjimo mokymą sunkina ir kiti veiksniai - mokymo situacijos dirbtinumas (nenatūralumas) ir pačios sakytinès kalbos sudètingumas.

Dialoginiam bendravimui būdinga daugybė komunikacinių- pragmatinių veiksnių. Tai:

- komunikacinè situacija (bendravimo vieta, laikas);

- komunikacijos partneriai (jų tapatybè, vaidmenys, nuostatos, rangas ir kt.);

- komunikacijos tikslas, kalbejimo intencijos (keitimasis informacija, vertinimas, komentaras, jausmų raiška, socialinès konvencijos);

- tema;

- kalbos priemonès, padedančios realizuoti pasakymą (morfologija, sintaksè, partnerių santykiai: $d u / S i e$, sag mal/sagen Sie mir mal...; situacija: hier, dort, drüben, nachher, 
vorher...; kalbejjimo intencijos, pvz., „pasiteirauti": Wissen Sie, ob, wann, wo...?; tema: teminis žodynas (Baldegger et al. 1980; Schank/Schoenthal 1983).

Ši sąrašą galètų papildyti neverbalinès bendravimo priemonès - kalbèjimo tempas, garso aukštumas ir stiprumas, gestai, mimika, judesiai ir kt.

Taigi aišku viena: besimokantiesiems sunku ¿̇veikti sudètingą užduotị kalbèti užsienio kalba, nes jiems trūksta ne tik kalbinių raiškos priemonių, bet ir gebejjimo sutelkti dèmesį $\mathfrak{i}$ visus komunikacijos aspektus iš karto.

\section{Tiriamojo darbo analizè}

Aukštųjų mokyklų studentai nefilologai greta monologinio kalbejjimo mokomi ir profesinio (dalykinio) dialogo užsienio kalba. Manytume, jog, mokant profesinio bendravimo, derètú remtis komunikacinėmis dialogų funkcijomis todèl, kad būtų galima nustatyti jų tipologinius skirtumus. Kitaip tariant, reikètų vadovautis tipologine dialogų klasifikacija.

Lingvistai (Schank, Schoenthal 1983; Henne, Rehnbock 1982) skiria įvairius dalykinio (profesinio) dialogo tipus: oficialaus pobūdžio diskusiją, pokalbị, interviu. Dialogai skirstomi ir i simetrinius ir asimetrinius. Simetriniai dialogai - tai buitinis pokalbis, keitimasis informacija, diskusija, fiktyvus, inscenizuotas dialogas ir natūralus dialogas. Pastarasis gali būti spontaniškas ir parengtas (natürliches und arrangiertes Gespräch). Asimetriniai dialogai - tai konsultacinio pobūdžio pokalbiai (Beratungsgepräche), apklausos (Befragungen), dialogai, būdingi aptarnavimo sričiai (Dienstleistungsgespräche).

Dialogai klasifikuojami ir pagal funkcinius tipus: tai dialogai, susiję su gamyba, planavimu, taip pat ir tokie, kurių tikslas - palaikyti, sumažinti psichologinę itampą, perteikti žinias (Wissensvermittlung), ittikinti pašnekovą (Überzeugungsgespräche). Pabrèžtina šioje tipologijoje diskusija visuomenès informavimo priemonèse
(Mediendiskussion) ir interviu (Techtmeier 1984: 56-61).

Šiame straipsnyje remiamasi patirtimi, sukaupta mokant profesinio bendravimo vokiečių kalba Vilniaus universiteto bibliotekininkystès specialybės studentus. Apklausę didžiųjų Lietuvos ir Vokietijos bibliotekų (Lietuvos nacionalinès M. Mažvydo bibliotekos ir Vokietijos valstybinès bibliotekos, Berlynas) darbuotojus, nustatėme dažniausias bibliotekininko ir skaitytojo, bibliotekos specialistų tarpusavio profesinio bendravimo situacijas. Tad manytume, kad, mokant profesinio (dalykinio) bendravimo, labiausiai taikytini keli dialogų tipai. Juos galètume ìvardyti taip:

- informacinis dialogas, kurio tikslas yra gauti ir teikti informaciją;

- probleminis dialogas;

- dialogas-ginčas, mokantis reikšti ir ginti savo nuomonę.

Šiuos dialogų tipus ir laikytume svarbiausiais mokant dalykinio (profesinio) bendravimo. Profesiniam bibliotekų darbuotojų bendravimui itin daug reikšmès turi informacinis dialogas. Tad kaip tik nuo jo ir reikètų pradèti mokyti. (Kaip, beje, ir kitų specialybių studentus.) Kadangi informaciniam dialogui būdinga ịvairūs profesinio bendravimo aspektai, tikslinga skirti jo šias rūšis:

- trumpas dialogas, kurio tikslas - pasiteirauti informacijos ir ją teikti;

- interviu;

- keitimasis informacija.

Aptarkime šias informacinio dialogo rūšis nuodugniau. Dialogas - informacijos teikimas skaitytojui pasiteiravus yra labai svarbus bibliotekose. Jis daugybę kartų per dieną vyksta tarp bibliotekininko (bibliografo) ir skaitytojo bibliotekos kataloguose, abonemente, skaityklose, kur knygos laisvai prieinamos. Štai keli autentiški šio dialogo ${ }^{\star}$ pavyzdžiai:

\footnotetext{
* Straipsnyje cituojami dialogai yra autentiški, autorès įrašyti j magnetine juosta Vokietijos valstybinèje bibliotekoje Berlyne.
} 
L: (Leser): Ich hätte eine Frage an Sie: Ich möchte gern wissen, ob die Nachschlagwerke, die in den Handbibliotheken der Lesesäle stehen, auch hier im: Alphabetischen Katalog verzeichnet sind?

B (Bibliothekar): Ja, selbstverständlich. Suchen Sie bitte in dieser Kartei (Šumskytè 1988: 24).

L: Ich möchte dieses Buch verlängern lassen.

B: Nein, tut mir leid, es ist nicht mehr möglich. Sie haben schon alle möglichen Leihfristen überzogen... (ib.: 35).

L: Guten Tag, können Sie mir bitte helfen? Ich habe hier eine Literaturangabe für einen Zeitschriftenaufsatz, aber die Zeitschrift ist abgekürzt, und ich komme mit der Auflösung nicht zurecht.

B: Ja, wir könen Ihnen helfen, wir haben einige Abkürzungsverzeichnisse. Ich gebe Ihnen mal dieses hier, den "Leistner". Es ist alphabetisch geordnet, dort können Sie nachsehen und die Abkürzung auflösen.

L: Gut. Schönen Dank (ib.: 26).

L: Guten Tag. Ich habe eine Frage, und zwar suche ich Literatur über das Leben und künstlerisches Schaffen von Max Beckmann.

B: Haben Sie bestimmte Titel? Kennen Sie schon Verfasser?... (ib.: 25).

Tokie trumpi mikrodialogai yra puiki mokymo medžiaga pradiniame mokymo etape, nes nuo pat pradžios padeda mokyti profesinio dialogo remiantis ne pavieniais pasakymais, o jų struktūriniais-semantiniais deriniais, kurie atspindi realaus bendravimo bibliotekoje situacijas. Kaip matome iš pavyzdžių, šių komunikacinių dialoginių vienetų forma paprastai yra klausimas-atsakymas, taip pat tvirtinimas ir iš jo kylantis klausimas. Tokius dialogus dèl jų stereotipiškumo ir dažnumo bibliotekininko darbe galima vadinti dialogais-šablonais.

Užsienio kalbų mokymo požiūriu svarbu, kad šie dialogai-šablonai, naudojami informacijai gauti (teikti), yra gera priemonè ittvirtinti ir teisingai vartoti pasakyme kalbejimo formules ir mokytis atsakyti trumpai, nes šnekamajai kalbai būdingi trumpi atsakymai. O studentai, kaip rodo praktika, mieliau renkasi išsamu atsakymą, nes jiems trūksta igūdžių vartoti trumpus atsakymus.

Norint tinkamai bendrauti šia informacinio dialogo forma, reikia išsiugdyti tokius gebejjimus: užmegzti ryši su pašnekovu; klausti informacijos (reaguoti i paklausimą); tinkamai pasirinkti kalbines priemones, skatinančias pradèti, tęsti ir baigti pasakymą; deramai naudoti kalbos ir etiketo formules klausiant informacijos; trumpai ir aiškiai teikti informaciją.

Kita vertus, trumpi pokalbiai, kurių struktūra yra klausimas-atsakymas, vyksta ir kitose profesinio bendravimo situacijose, netgi sudètingiausioje iš jų - mokslinejje diskusijoje, pavyzdžiui, prieš svarstant išklausytą pranešimą arba baigiant ji svarstyti. Kartais diskutuojama apskritai tenkinantis pranešèjo atsakymais $\mathfrak{i}$ klausimus.

Svarbu ir tai, kad trumpas dialogas, kurio paskirtis - teirautis informacijos, deda kitų informacinio dialogo rūšių mokymo pagrindus, pavyzdžiui, interviu. Interviu verta aptarti išsamiau, nes jis itin tinka mokymui. Studentai mègsta interviu, ypač kai jo mokoma kaip vaidybinio žaidimo.

Tradicinè interviu forma yra schema „klausimas-atsakymas“, vienam iš pašnekovų keliant klausimus, o kitam ị juos atsakant. Tačiau, skirtingai nei aptarto pokalbio, kiekvienas interviu klausimas turi būti kruopščiai apgalvotas ir tinkamai suformuluotas, kad paskatintų pašnekovą atskleisti tam tikro pobūdžio informaciją. Interviu - tai kryptingas pokalbis, kurị reguliuoja ir norima linkme nukreipia imantysis interviu, dažniausiai atstovaujantis žiniasklaidai (spaudai, televizijai, radijui), taigi korespondentas, reporteris. Klausinejama kurios nors srities specialisto ar visuomenès veikèjo.

Lingvistai nurodo tokius svarbiausius interviu bruožus: jame dalyvauja du pašnekovai, iš kurių vienas vyrauja (Rang: Ein Sprecher privilegiert). Kadangi interviu vyksta pašnekovams glaudžiai bendraujant (Face-to-FaceInteraktion) ir jo paskirtis - teikti informaciją per visuomenès informavimo priemones - po- 
kalbio tema būna iš anksto numatyta (Schank/ Schoenthal 1983: 41). İdomu tai, kad žodžių, kuriuos ištaria duodantysis interviu, yra vidutiniškai tris kartus daugiau nei korespondento. Taigi pasakymo apimtis priklauso nuo to, kuris iš pašnekovų pokalbyje vyrauja, t. y. duodantysis interviu. Iš imančiojo interviu laukiama vis daugiau klausimų, skatinančių pašnekovą pateikti kuo daugiau informacijos, duodant jam galimybę reikšti ar argumentuoti savo požiūrị. Tad nenuostabu, kad skirtingus abieju pašnekovų vaidmenis atspindi ir jų pasakymų sintaksè. Apskaičiuota, kad korespondento kalboje paprasti sakiniai sudaro $51,6 \%$, o duodantysis interviu jų vartoja $45,7 \% .29 \%$ duodančiojo interviu sakinių - prijungiamieji, turintys daugiau nei vieną šalutinị sakinị, o korespondentas pavartoja vos kelis šalutinius sakinius ( Berens 1975: 65). Analizuojant interviu, kuriuose abu pašnekovai buvo lygiateisiai [Rang: Sprecher gleichberechtigt], paaiškèjo, kad jų replikų apimtis ir trukmé buvo vienoda (Schank/Schoenthal 1983: 42).

Taigi mokant interviu derètų neišleisti iš akių anksčiau aprašytų jo savybių ir abiejų pašnekovų vaidmenų. Kaip jau minejome, imantysis interviu vadovauja pokalbiui, jo komunikacinis tikslas - gauti informaciją. Tačiau, nors jo replikos ir trumpesnès nei pašnekovo, jis turi gebèti aiškiai ir tiksliai formuluoti klausimus, šitaip nurodydamas tikètinos informacijos pobūdị. Kita korespondento užduotis - trumpomis replikomis reguliuoti pašnekovo kalbą (pvz., Darf ich mal unterbrechen? /Genau! Genau das meine ich!/ Kaum möglich!/ Unwahrscheinlich!/ Das ist eine gute Idee!). Pragmatinis-komunikacinis imančiojo interviu replikų poveikis sustiprès tinkamai naudojant būdingas interviu kalbèjimo formules (pvz., Würden Sie bitte sagen/erklären.../Welche Rolle spielt dabei.../Wie stellen. Sie sich...vor?/In diesem Zusammenhang/ zum Schluss noch eine Frage ... ir kt.).

Duodantysis interviu neturi užmiršti, kad jo užduotis - teikti informaciją, todèl kartais jo pasakymas, jei yra pernelyg platus ir išsamus, gali priartèti prie monologo.
Baigiant nagrinèti interviu, galima pridurti, jog kartais interviu gali prarasti savo žanro grynumą ir virsti pašnekesiu. Taip atsitinka, kai korespondentas ne tik pateikia klausimus, bet ir keičiasi su pašnekovu informacija arba net ima samprotauti. Šiuo atveju korespondento klausimai praranda kamantinejjimo pobūdị, būdingą interviu, ir per pašnekesį keliami tarsi savaime. Pastarąją aplinkybę derètų išnaudoti mokant studentus, nes nuo tokio interviu galima pereiti prie kitos informacinio dialogo rūšies - specialistų pokalbio, kurio tikslas yra dalintis (keistis) informacija. Šiame informaciniame dialoge nebebūdingos interviu schemos „klausimas-atsakymas", nes nelieka duodančiojo interviu. Pokalbyje dalyvauja lygiateisiai pašnekovai, aptariantys tam tikrą dalykinę problemą. Šios rūšies informaciniam dialogui būdingas ne tik abiejų pašnekovų suinteresuotumas gauti informaciją, bet ir interesų bendrumas aptariama tema. Todèl pašnekovai vienas iš kito siekia ne tik gauti informaciją, bet ir dalintis tuo, kas jiems žinoma. Kita vertus, ir toks pokalbis gali kaitaliotis su interviu, nes jame gali atsirasti schema „klausimas-atsakymas" bei kamantinejjamasis klausimų pobūdis. Taigi svarbiausia rodyti iniciatyvą užduodant klausimus. Todèl ugdytini šie gebejimai: gebèti aktyviai klausinèti; sutikti (nesutikti) su pašnekovu; reikšti savo požiūrịi; gauti norimą informaciją bei ją teikti; reikšti domèjimąsi, nuostatą, įsitikinimą.

Informacinis dialogas parengia sudètingesnio profesinio (dalykinio) dialogo tipo - probleminio dialogo - mokymą. Jo uždavinys - spręsti probleminę situaciją, keičiantis replikomis bei $i$ jas reaguojant.

Profesinio specialistų bendravimo probleminis dialogas (o kartais - ir polilogas, jei jame dalyvauja daugiau nei du pašnekovai) yra dalykinio pobūdžio. Jame aptariami griežtai nustatyti klausimai. Mokant probleminio dialogo, privalu ugdyti šiuos gebejimus: argumentuoti savo požiūrił; sutikti (nesutikti) su pašnekovu; reikšti abejojimą dèl pašnekovo nuomonès teisingumo (pagrįstumo); itikinti pašnekovą logiškai formuluojant savo teigini (pasakymą). 
Mokant probleminio dialogo (polilogo), reiketuc vadovautis tokia taisykle: kiekvienas kalbètojas prisideda prie problemos sprendimo ir sutelkia dèmesi i dalykinę pokalbio pusę. Šiuo požiūriu gali būti naudingos šios pragmatinio pobūdžio metodinès rekomendacijos:

- atidžiai išklausykite pašnekovą, teiraukitès jo nuomonès, išsamios informacijos, prieštaraukite;

- jei manote, kad pašnekovo požiūris teisingas, pasakykite jam tai;

- nesivelkite i ilgus monologus, kalbèkite trumpai ir dalykiškai;

- neaiškumus šalinkite iš karto;

- pokalbiui nukrypus nuo temos, arba, jei manote, kad jis pateko i aklavietę, atkreipkite i tai pašnekovo dèmesị (Wernicke 1990: 91).

Jei nepavyksta rasti aiškaus problemos sprendimo, dialogas igyja polemini pobūdị ir gali peraugti i ginčą. Jame susiduria dvi prieštaraujančios nuomonès, tad reikia nustatyti, kuri iš ju teisinga, o kuri - klaidinga. Biblioteku darbuotojai dažnai atsiduria tokiose situacijose bendraudami su skaitytojais. Šis dialogas iliustruoja vieną iš jų:

L: Ich möchte gern das Buch hier abgeben.

$B$ : Ja, jetzt muss ich Ihnen leider sagen. Sie haben die Leihfrist sehr überzogen. Haben sie denn nicht gewusst, wie lange die Leihfrist dauert? Sie haben doch einen Termin von uns bekommen.

L: Ja, aber den Zettel habe ich verbummelt. Ich dachte ja, Sie mahnen.

$B: J a, b l o ß$ wir sind ja nicht dazu verpflichtet, Ihnen eine extra Karte zu schicken, um sie darauf aufmerksam zu machen, wann die Bücher zurückzugeben sind.

L: Na ja, bloß man hat ja mehr im Kopf als nur Ihre Bücher...

B: Na das mag ja sein, aber ich muss Sie ganz ernst darauf aufmerksam mahcen, dass das jetzt ganz schön teuer für Sie werden kann. Sie müssen jetzt über 5 Euro zahlen.

L: Könte ich mal bitte sehen, wie Sie zu dieser Summe kommen?
B: Ja, natürlich. Also, es ist ganz einfach: Für die erste Woche, die Sie überziehen, rechnen wir Ihnen.... (Šumskyte 1988: 42).

Dialogas-ginčas gali vykti ir tarp specialistų. Dialogo-ginčo mokyti yra kur kas sunkiau, nes jis plètojamas pasitelkiant vertinimą ir argumentavimą. Pašnekovai turi ne tik keistis nuomonèmis, bet ir gebèti lyginti bei vertinti susiduriančių koncepcijų prasminius elementus, rasti silpnas oponento argumentų grandis bei jas atmesti. Akivaizdu, kad, norint polemizuoti užsienio kalba, reikia gerai ją mokèti. Būtina turèti nemažą kalbos priemonių atsargą, gebèti tinkamai naudoti kalbos struktūras, susijusias su įrodinejjimo bei paneigimo logika. Vis dèlto manytume, kad bent pavienių dialogo-ginčo elementų studentai turètų būti mokomi, pavyzdžiui, pasitelkus argumentacinị dialogą. Jo užduotis gali būti formuluojama taip: „Wählen Sie sich einenPartner. Sie gehen von den Argumenten auf der linken Seite aus. Ihr Partner von denen auf der rechten. Bevor Sie anfangen, lesen Sie bitte erst die Sprechformeln in der Mitte. "Šioje užduotyje kiekvieno kalbètojo argumentai pateikiami kaip trumpi teminai impulsai, taip pat ir kalbejjimo formulès skirtos tinkamai komunikacinių ketinimų raiškai (prieštaravimo, neigimo, pritarimo, abejojimo, argumentavimo ir t. t.). Išmokus aktyviai dalyvauti dialoge-ginče, galima pereiti prie sudètingiausios dialogo (polilogo) formos - diskusijos.

Ir dialogas-ginčas, ir diskusija vyksta susiduriant priešingoms nuomonėms ir problemas sprendžiant užsienio kalba. Abi šios pokalbio formos turtina mokymą kūrybiškais momentais ir skatina besimokančiuosius tobulinti savo raiškos gebejjimus studijuojama užsienio kalba.

Norint sèkmingai dalyvauti dialoge-ginče ar diskusijoje, būtina gebėti: įtikinamai reikšti (pabrèžti) savo požiūrị; argumentuoti savo nuomonę; kritikuoti pašnekovą; ịrodinèti (vertinti) faktus; visiškai pakeisti pašnekovo požiūrị pateikiant svarių argumentų.

Galima daryti išvadą, kad užsienio kalbos, kaip bendravimo priemonès, mokymo efektyvumą lemia tinkamai parengta mokymo me- 
džiaga. Mokant studentus bendrauti jų būsimos specialybès temomis, būtina pasitelkti profesinio (dalykinio) dialogo (geriausia - autentiško) pavyzdžiu, atspindinčių visas mokslinès dialoginès kalbos ypatybes ir, remiantis dialogų tipologija, parengti specialias užduotis ir situacinio pobūdžio pratimus - treniruojamuosius ir komunikacinius. Šių pratimų turinys turètų būti profesinio bendravimo situacijos, artimos realiai specialistų komunikacijai.

Straipsnyje nagrinejjama tema yra svarbi ir gali būti sèkmingai tiriama toliau - rengiant analogišką profesinio (dalykinio) dialogo mokymo metodiką ne tik bibliotekininkystès, bet ir kitų humanitarinių specialybių studentams, pvz., žurnalistams, istorikams, sociologams ir kt.

\section{Literatūra}

Baldegger, M.; Müller, M; Schneider, G. 1980. Kontaktschwelle Deutsch als Fremdsprache. Hg. Europarat für kulturelle Zusammenarbeit. Berlin: Langenscheidt.

Berens, F. J. 1975. Analyse des Sprechverhaltens im Redekonstellationstyp "Interview". München: Hueber.

Dirven, R. 1977. “Aspekte der Hörverstehensdidaktik”, in Hörverständnis im Fremdsprachenunterricht. Kronberg: Scriptor, 1-17.

Henne, H.; Rehnbock, H. 1982. Einführung in die Gesprächsanalyse. Berlin: de Gruyter.

Schank, G.; Schoenthal, G. 1983. Gesprochene Sprache. Eine Einführung in Forschungsansätze und Analysemethoden. Tübingen: Niemeyer.

Šumskytè, G. 1988. Profesinis dialogas vokiečių kalba. Pratybų užduotys bibliotekininkystès ir bibliografijos specialybès studentams. Vilnius: Vilniaus universiteto leidykla.

Techtmeier, B. 1984. Das Gespräch. Funktionen, Normen. Strukturen. Berlin: AkademieVerlag.

Wernicke, U. 1990. Sprachwissen. Hamburg: Technik. 


\title{
DIALOGTYPOLOGIE UND VERMITTLUNG DES FACHORIENTIERTEN GESPRÄCHS IM STUDIENBEGLEITENDEN FREMDSPRACHENUNTERRICHT
}

\author{
Gražina Šumskytè
}

Der Artikel beschäftigt sich mit der Aufstellung der Typologie von fach-und berufsorientierten Dialogen. Sie hat zum Ziel dazu beizutragen, den studienbegleitenden Fremdsprachenunterricht erfolgreicher und zielgerichteter zu gestalten. Im Artikel werden die Fragen der Vermittlung des fach- und berufsorientierten Dialogs den Studenten der Fachrichtung Bibliothekswesen behandelt. Mit Hilfe einer Befragung der Spezialisten der größten litauischen und deutschen Bibliotheken wurden die typischen Situationen der interpersonalen Kommunikation bei der Bibliotheksbenutzung (in der Auskuftsstelle, an der Ausleihstelle und Ausleihberatung) ermittelt. Infolgedessen lassen sich zu Unterrichtszwecken folgende Dialogtypen empfehlen: informierender Dialog, Problemdialog, Streitgespräch. Bei der Aufbereitung der Unterrichtsmaterialien ist es von authentischen Dialogen, die sich in typischen Situationen der fachbezogenen Kommunikation abspielen, auszugehen.

Schlüsselwörter: Faktoren der mündlichen Kommunikation, Dialogtypologie, situativer Rang des betreffenden Sprechers, Interviewschema, informierender Dialog, Problemdialog, Streitgespräch.

Iteikta 2006-01-16; priimta 2006-02-22 